\title{
DISTRIBUSI PENDAPATAN DI INDONESIA Proses Pemerataan dan Pemiskinan
}

\author{
Didit Purnomo \\ Fakultas Ekonomi Universitas Muhammadiyah Surakarta
}

\begin{abstract}
This article presents the issue of income disparities, especially the phenomenon in Indonesia. Generally, the wealth of a country could be analyzed by its GDP rate so the society's income distribution of the country is able to be analyzed also. The disparities is still occurred in Indonesia. The empirical data shows that there's a lot of disparities among regions, especially between West side of Indonesia and East side of Indonesia.

A few questions appeared consider these realities, is the development move forward or backward? Is it straight to equality or poverty?
\end{abstract}

\section{PENDAHULUAN}

Pendapatan Nasional merupakan salah satu indikator untuk mengukur kesejahteraan perkembangan ekonomi suatu negara (wilayah) dari waktu ke waktu. Hal yang perlu kita ketahui bahwa dalam perhitungan pendapatan nasional adalah menerapkan konsep rata-rata, sehingga diperkirakan tidak mencerminkan unsur kemerataan atau keadilan. Keadaan ini kemungkinan sekali tidak terpantaunya distribusi pendapatan secara merata.

Sumber yang ditampilkan oleh organisasi perburuhan internasional (ILO) mengidentifikasikan (memprediksikan) bahwa dua dari penduduk Indonesia akan berada di bawah garis kemiskinan menjelang tahun 1999 bila perekonomian tidak segera membaik (Kompas, September 1998). Kondisi ini sangat berkaitan dengan ketidakmerataan pendapatan yang selama ini terjadi. Standar pengukuran garis kemiskinan di Indonesia menurut International Labour Organization jauh lebih rendah dibanding standar internasional. Menurut ukuran 
internasional, sebuah masyarakat akan tergolong miskin atau berada di bawah garis kemiskinan bila pendapatannya dibawah satu dollar AS untuk wilayah perkotaan, sedang untuk pedesaan dibawah 80 sen dollar AS per-harinya. Padahal, di Indonesia, ukuran sebuah masyarakat dikatakan berada di bawah garis kemiskinan bila per-harinya pendapatan hanya kurang dari 55 sen dollar AS (perkotaan). Perhitungan ini berasumsi ketika nilai setiap dollar-nya masih Rp. 2300,(awal 1997), maka dapat dibayangkan bila asumsi dollar lebih dari nilai tersebut. Belum lagi keadaan ini diperparah oleh masa krisis sekarang ini, sehingga jutaan insan menjadi tidak produktif.

Ukuran lain yang sering digunakan (di Indonesia) adalah kemampuan seseorang mengkonsumsi minimal 2.200 kalori perharinya (salah satu ukuran garis kemiskinan). Ukuran-ukuran di atas menunjukkan masih rendahnya standar minimal untuk tingkat kehidupan di Indonesia.

Menyinggung permasalahan di atas yaitu berkaitan ketidakmerataan distribusi pendapatan maka dalam tulisan ini akan menyimak berbagai indikator (konsep-konsep) yang digunakan dalam mengukur pembagian hasil pembangunan (pendapatan nasional). Sehingga secara teoritis dapat kita ketahui apakah 'kue pembangunan' yang dihasilkan memberikan kesejahteraan ataukah justru semakin memiskinkan masyarakat.

\section{INDIKATOR DISTRIBUSI PENDAPATAN}

Pemerataan hasil-hasil pembangunan secara umum selalu dikaitkan dengan permasalahan kemiskinan. Pada kenyataannya yang terjadi adalah jarak (gap) antara golongan yang disebut si kaya dengan golongan si miskin terlihat semakin lebar. Dengan demikian tujuan dari penerapan berbagai kebijakan ekonomi adalah menciptakan kemakmuran bagi seluruh 'penghuni negeri' seadil-adilnya, dengan kata lain mengurangi kemiskinan. Pada sub-bab ini akan ditampilan beberapa indikator atau konsep-konsep yang mengukur distribusi pendapatan.

Tiga indikator yang seringkali dipergunakan, yaitu:

1. Indeks Gini (Gini Coefficient) 
2. Kurva Lorenz, dan

3. Kriteria Bank Dunia

Indeks Gini merupakan suatu koefisien yang berkisar antara angka 0 (nol) hingga 1 (satu). Kisaran angka tersebut menjelaskan kadar kemerataan atau ketimpangan distribusi pendapatan nasional. Keadaan di mana terdapat adanya pemerataan dari distribusi pendapatan diperlihatkan besarnya koefisien yang mendekati nol, sedang kecenderungan terjadinya suatu ketimpangan akan ditunjukkan besarnya angka koefisien mendekati 1 . Sebagaimana dalam indikator ekonomi (Suseno, 1990), Indeks Gini secara matematis dapat dirumuskan sebagai berikut :

$$
\mathrm{GC}=1-\sum_{1}^{\mathrm{n}} \cdot\left(\mathrm{X}_{\mathrm{i}+1}-\mathrm{X}_{\mathrm{i}}\right)\left(\mathrm{Y}_{\mathrm{i}+1}-\mathrm{Y}_{\mathrm{i}}\right)
$$

Atau

$$
\mathrm{GC}=\sum_{i}^{\mathrm{n}} \cdot \mathrm{f}_{\mathrm{i}} \cdot\left(\mathrm{Y}_{\mathrm{i}+1}-\mathrm{Y}_{\mathrm{i}}\right)
$$

Dimana :

$\mathrm{GC}=$ Angka Gini Koefisien'

$\mathrm{X}_{\mathrm{i}}=$ Proporsi jumlah rumah tangga kumulatif dalam kelas I

$Y_{i}=$ Proporsi jumlah pendapatan rumah tangga kumulatif dalam kelas I

$\mathrm{f}_{\mathrm{i}}=$ Proporsi jumlah rumah tangga dalam kelas I

' Angka GC (Gini coefisien) berkisar antara 0 sampai dengan 1. Angka GC semakin mendekati 0 maka menunjukkan adanya kemerataan dalam distribusi

Distribusi Pendapatan ...... (Didit Purnomo) 
Di sisi lain Koefisien Gini dapat ditaksir secara visual dari kurva Lorenz, yaitu kurva yang menggambarkan distribusi komulatif pendapatan nasional di kalangan lapisan-lapisan penduduk (lihat gambar 1)

\section{Gambar 1. Kurva Lorenz}

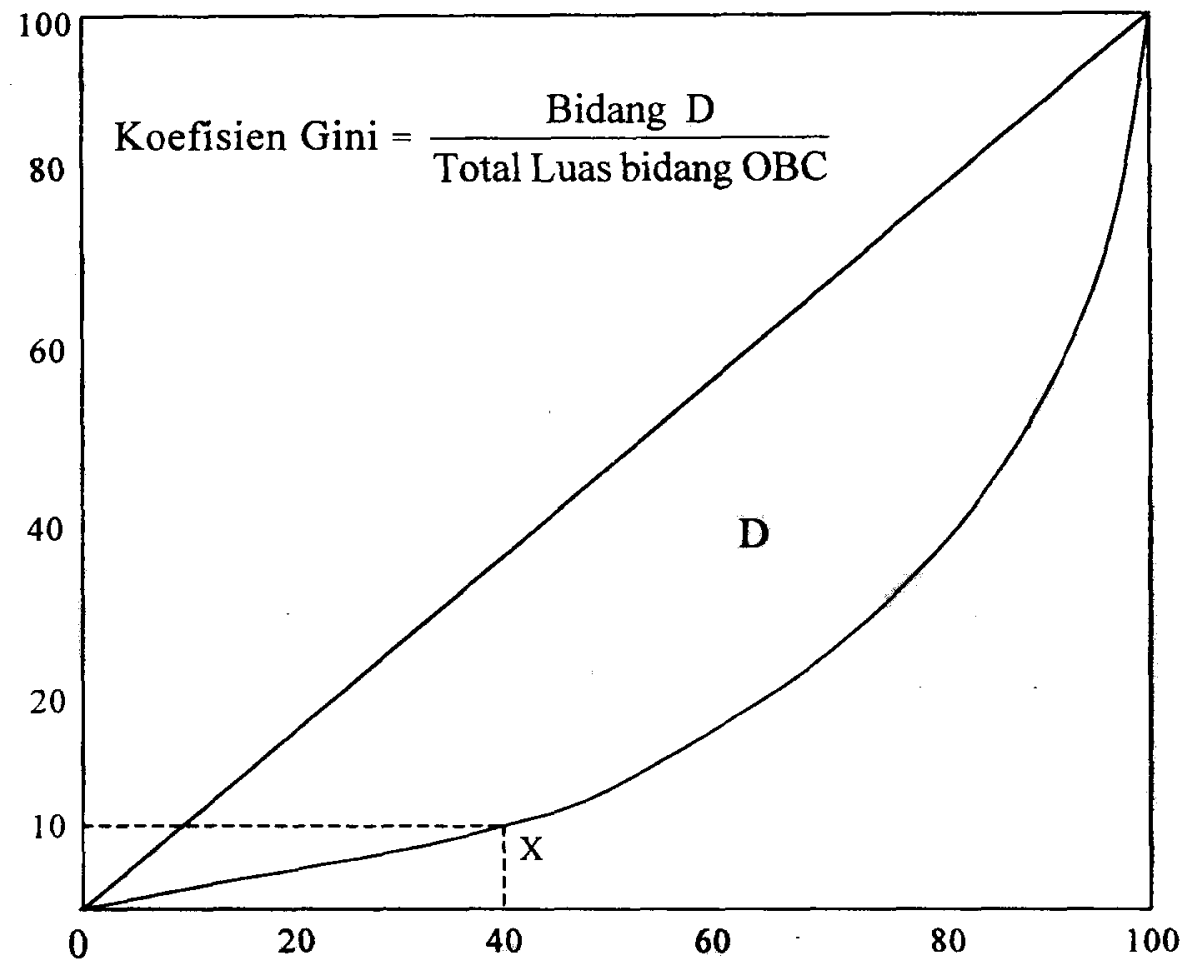

Keterangan:

Titik X mencerminkan $40 \%$ penduduk berpendapatan terendah memiliki $10 \%$ GNP

pendapatan, sedang angka GC yang mendekati 1 menunjukkan ketidakmerataan 
Sedang konsep menurut Bank Dunia didasarkan atas porsi pendapatan nasional yang dinikmati oleh tiga kelompok penduduk, yaitu: pertama, penduduk dengan pendapatan rendah yang merupakan $40 \%$ dari jumlah penduduk ; kedua, penduduk dengan pendapatan menengah yang merupakan $40 \%$ jumlah penduduk ; ketiga, penduduk dengan pendapatan tinggi yang merupakan $20 \%$ jumlah penduduk. "Selanjutnya ketidakmerataan atau ketimpangan dinyatakan tinggi bila $40 \%$ penduduk berpendapatan rendah menikmati kurang dari $12 \%$ pendapatan nasional ; dinyatakan timpang sedang apabila $40 \%$ penduduk yang termasuk golongan tersebut menikmati antara $12 \%$ hingga $17 \%$ pendapatan nasional ; dan digolongkan timpang rendah apabila $40 \%$ penduduk berpenghasilan rendah menikmati lebih dari $17 \%$ pendapatan nasional (Tambunan, 1996 \& Dumairy, 1997).

\section{KETIDAKMERATAAN PENDAPATAN NASIONAL}

Telah disinggung di atas bahwa salah satu indikator distribusi pendapatan, yaitu Indeks Gini menjadi tolak ukur dalam pembagian pendapatan antar lapisan di suatu wilayah negara. Walaupun ukuran ini bukanlah merupakan indikator yang sempurna dalam hal ketidakmerataan termasuk di dalamnya adalah ketimpangan dan kesenjangan distribusi pendapatan antar lapisan, namun demikian indikator indeks gini cukup representatif dalam memberikan diskriptif tentang kecenderungan secara umum dalam pola pembangunan pendapatan.

Kalaupun kita melihat keadaan yang terjadi di tanah air kita Indonesia, berkaitan dengan koefisien indeks gini, ternyata terlihat cukup fluktuatif, yang berarti mencerminkan bahwa 'pembagian kue nasional' mengalami kenaikan di satu masa lain (lihat tabel 1).

Fenomena yang terjadi di Indonesia pada saat memasuki pelita III diperlihatkan dengan menurunnya Koefisien Gini yang berarti berkurangnya ketimpangan, dimana pemerintah orde baru mulai menempatkan prioritas pemerataan pada urutan pertama dalam formasi Trilogi Pembangunan. Kebijakan ini dikemas dalam sebuah paket kebijakan yang sering kita kenal dengan Delapan Jalur Pemerataan. Dalam kebijakan ini berisikan tujuan-tujuan yang hendak dicapai pemerintah waktu itu (orde baru), yaitu mulai dari bidang kebutuhan pokok (sandang, pangan dan papan), pendidikan, pekerjaan, penda-

Distribusi Pendapatan ...... (Didit Purnomo) 
patan sampai partisipasi wanita dan kaum muda serta di bidang keadilan.

Tabel 1. Fenomena Koefisien Gini di Indonesia, periode 1960-an hingga 1990-an

\begin{tabular}{|c|c|c|c|}
\hline Tahun & Koefisien & Tahun & Koefisien \\
\hline 1965 & 0.389 & 1978 & 0.380 \\
1969 & 0.339 & 1979 & 0.381 \\
1970 & 0.346 & 1980 & 0.340 \\
1971 & 0.315 & 1981 & 0.330 \\
1972 & 0.313 & 1982 & 0.355 \\
1973 & 0.315 & 1984 & 0.330 \\
1974 & 0.335 & 1985 & 0.364 \\
1975 & 0.326 & 1987 & 0.320 \\
1976 & 0.346 & 1990 & 0.320 \\
1977 & 0.337 & 1993 & 0.340 \\
\hline
\end{tabular}

Sumber : BPS (berbagai tahun), Sri Bintang Pamungkas (1984), Sundrum, Van Gineken - diambil dari Dumairy, $1997: 56$

Namun demikian, disinyalir bahwa paket pemerataan tersebut tidak memberikan pemerataan seperti selama ini diharapkan, tetapi justru memberikan ketimpangan dengan semakin lebarnya 'garis pemisah' antara si kaya dengan si miskin. Bahwa sebagian besar 'kue pembangunan' (Purnomo, 1998 : "Menyimak Sejarah Perekonomian Indonesia") hanya dinikmati oleh segelintir makhluk yang disebut 'konglomerat'.

Belum lagi kenyataan yang terjadi dewasa ini muncul kepermukaan sebagai ketidakpuasan atas apa yang terjadi berkaitan dengan pola distribusi yang selama ini tidak memberikan equity pada 
rakyat banyak. Sebagai contoh aktual yaitu 'geger Freeport', di mana proyek tambang emas tersebut pada awalnya diharapkan akan memberikan kemakmuran rakyat dan mengangkat potensi daerah (Irian Jaya), namun pada akhir cerita justru menyengsarakan rakyat pribumi (khususnya). Dan masih banyak lagi tentang kasuk-kasus serupa dalam hal ini berkaitan dengan pola distribusi yang berlaku di tanah air selama kurang lebih 30 tahun yang menjadi bukti (data) bahwa yang telah terjadi adalah 'proses menuju kemiskinan'.

\section{PERBANDINGAN: INDONESIA DAN NEGARA BERKEM- BANG LAIN}

Dalam perbandingan internasional, distribusi pendapatan nasional Indonesia tidak lebih buruk bila dibandingkan dengan beberapa negara tetangga di Asia (lihat tabel 2). Berdasarkan konsep World Bank, bila dibandingkan dengan Republik Rakyat Cina (RRC), Malaysia, Filipina dan Thailand, distribusi pendapatan nasional Indonesia relatif lebih merata.

Keadaan yang hampir sama diperlihatkan Indonesia diantara negara-negara berkembang lainnya dalam pendapatan per-kapita dan ketimpangan distribusi pendapatan (lihat tabel 3 ).

Tabel 2. Distribusi Pendapatan Nasional Beberapa Negara Asia

\begin{tabular}{|c|c|c|c|c|}
\hline \multirow{2}{*}{ Negara } & \multirow{2}{*}{ Tahun } & Lapisan & Penduduk & Berpendapatan \\
\cline { 3 - 5 } & & $40 \%$ Bawah & $40 \%$ Tengah & $20 \%$ Tengah \\
\hline Indonesia & 1990 & 20.8 & 36.9 & 42.3 \\
Malaysia & 1989 & 12.9 & 33.4 & 53.7 \\
Filipina & 1988 & 16.6 & 35.6 & 47.8 \\
Thailand & 1988 & 15.5 & 23.8 & 50.7 \\
India & 1990 & 21.3 & 37.4 & 41.3 \\
RRC & 1990 & 17.4 & 40.8 & 41.8 \\
\hline
\end{tabular}

Sumber : World Development Report, 1995, diambil dari Dumairy, 1997 
Tabel 3. Pendapatan Per-Kapita dan Ketimpangan di Negaranegara berkembang

\begin{tabular}{|l|c|c|c|c|}
\hline \multicolumn{1}{|c|}{ Negara } & $\begin{array}{c}\text { GNP per- } \\
\text { kapita 1993 } \\
\text { (USS) }\end{array}$ & $\begin{array}{c}\text { Pangsa } \\
\text { Pendptn 40\% } \\
\text { RT termiskin } \\
\text { '80-91 }\end{array}$ & $\begin{array}{c}\text { Rasio Pendptn } \\
\text { 20\% RT } \\
\text { terkaya thd } \\
\text { 20\% RT } \\
\text { termiskin }\end{array}$ & $\begin{array}{c}\text { Koefisien } \\
\text { Gini 1980- } \\
\text { an }\end{array}$ \\
\hline Bangladesh & 220 & 22.9 & 4.1 & 0.34 \\
Kenya & 270 & 9.1 & 22.6 & 0.55 \\
Srilangka & 600 & 13.3 & 11.5 & 0.45 \\
Indonesia & 730 & 20.5 & 4.9 & 0.31 \\
Filipina & 830 & 16.6 & 7.4 & 0.45 \\
Jamaika & 1390 & 15.9 & 8.1 & 0.46 \\
Peru & 1490 & 14.1 & 10.5 & 0.31 \\
KostaRika & 2160 & 13.1 & 12.7 & 0.42 \\
Brasil & 3120 & 7.0 & 32.1 & 0.57 \\
Malaysia & 3160 & 12.9 & 11.7 & 0.48 \\
\hline
\end{tabular}

Sumber : Human Development Report, 1992 \& 1994, diambil dari Michael P Todaro, ed.6 : 177

\section{KEADAAN DI INDONESIA: KETIMPANGAN ANTAR KELOMPOK MASYARAKAT}

Kalau boleh dikatakan, selama Pembangunan Jangka Panjang Tahap I (PJPT I) Indonesia telah menampilkan 'keberhasilan' pembangunan nasional yang cukup berarti, yaitu dilihat dari 'economic growth' dan 'pengentasan kemiskinan'-nya, serta peningkatan dalam 'kualitas hidup'. Namun demikian keberhasilan menanggulangi ketimpangan sesuai amanat GBHN lewat Trilogi Pembangunan belum cukup memuaskan. Ketimpangan antar berbagai kelompok pendapatan dan antar daerah: desa dan kota, Jawa dan luar Jawa. Kawasan Indonesia Timur dan Kawasan Indonesia Barat masih merupakan permasalahan yang harus diselesaikan (Sondakh, 1994).

Permasalahan di atas kemungkinan sekali bersumber pada terbukanya ekonomi pedesaan (daerah) terhadap ekonomi pasar (kekuatan), sehingga hanya bagi mereka saja yang memiliki akses terhadap modal, kredit, informasi dan penguasa yang dapat memanfaatkan kesempatan ekonomi terbuka. 
Banyak kajian dan penelitian yang berkaitan dengan distribusi pendapatan antar kelompok pendapatan masyarakat (daerah) pernah dilakukan oleh berbagai peneliti dan ekonom ${ }^{2}$ (lihat tabel 4, 5 dan tabel 6).

Tabel 4. Distribusi Pendapatan dalam Gini Ratio Indonesia, 1970-1990

\begin{tabular}{|c|c|c|c|c|c|}
\hline \multirow{2}{*}{ Tahun } & Indonesia & Jawa & Luar Jawa & \multicolumn{2}{|c|}{ Indonesia } \\
\cline { 2 - 6 } & Kota & Desa & $\begin{array}{c}\text { Kota \& } \\
\text { Desa }\end{array}$ & $\begin{array}{c}\text { Kota \& } \\
\text { Desa }\end{array}$ & $\begin{array}{c}\text { Kota \& } \\
\text { Desa }\end{array}$ \\
\hline 1970 & 0.3265 & 0.3386 & 0.3211 & 0.3281 & 0.3456 \\
1976 & 0.3681 & 0.3044 & 0.3572 & 0.3108 & 0.3459 \\
1981 & 0.3341 & 0.2598 & 0.3291 & 0.2855 & 0.3020 \\
1984 & 0.3200 & 0.2300 & - & - & 0.3300 \\
1980 & 0.3376 & 0.2519 & - & - & 0.3200 \\
\hline
\end{tabular}

Sumber : Th 1970-1976 dari Sundrum (1979); Th. 1981 dari Asra (!990). Th. 1990 dari BPS (1992).

Tabel di atas menunjukan bahwa secara keseluruhan tidak terlihat perbaikan perbaikan yang berarti dalam disparitas pendapatan antar kelompok pendapatan (1970-1990) dan disparitas pendapatan di perkotaan yang lebih besar dari pedesaan.

\footnotetext{
${ }^{2}$ Sundrum, dalam Income Distribution, 1970-1976; Asra dalam Inequality Trends in Indonesia, 1968-1981 ; BPS, dalam "Nilai Tukar Petani Seluruh Propinsi Luar Jawa, 1987-1990 ; Parera ; Sondakh, 1992.
} 
Tabel 5. Gini Rasio Tahun 1984 - 1990 :

\begin{tabular}{|c|c|c|c|c|c|c|}
\hline \multirow{2}{*}{ Tahun } & \multicolumn{3}{|c|}{1984} & \multicolumn{3}{|c|}{1990} \\
\cline { 2 - 7 } & Kota & Desa & K \& D & Kota & Desa & K \& D \\
\hline \multirow{2}{*}{ SulUt } & 0.2950 & 0.3232 & 0.3516 & 0.2537 & 0.6880 & 0.2546 \\
SulSel & 0.3188 & 0.3319 & 0.3473 & 0.2802 & 0.2599 & 0.2956 \\
SulTeng & 0.2773 & 0.2504 & 0.2974 & 0.2156 & 0.2357 & 0.2695 \\
SulTra & 0.3192 & 0.2924 & 0.3153 & 0.2958 & 0.2694 & 0.3018 \\
IrJa & 0.4212 & 0.3131 & 0.3734 & 0.2753 & 0.2818 & 0.3284 \\
N T B & - & - & - & - & - & - \\
& & & & & & \\
\hline Indonesia & 0.3200 & 0.2300 & 0.3300 & 0.3376 & 02519 & 0.3213 \\
\hline
\end{tabular}

Tabel 6. Distribusi Pendapat Tahun 1984-1990 (Kota-Desa):

\begin{tabular}{|c|c|c|c|c|c|c|}
\hline \multirow{2}{*}{ Tahun } & \multicolumn{3}{|c|}{1984} & \multicolumn{3}{|c|}{1990} \\
\cline { 2 - 7 } & $40 \%$ & $40 \%$ & $20 \%$ & $40 \%$ & $40 \%$ & $20 \%$ \\
\hline \multirow{3}{*}{ SulUt } & 19.53 & 38.05 & 42.42 & 25.07 & 38.60 & 35.32 \\
SulSel & 19.25 & 37.64 & 46.11 & 22.10 & 38.38 & 39.52 \\
SulTeng & 22.34 & 37.86 & 39.80 & 23.71 & 38.36 & 37.93 \\
SulTra & 20.98 & 38.52 & 40.50 & 22.19 & 36.88 & 40.98 \\
IrJa & 18.33 & 35.66 & 46.01 & 19.97 & 38.46 & 41.57 \\
N T B & 21.69 & 38.46 & 39.35 & 23.03 & 36.52 & 40.44 \\
& & & & & & \\
\hline Indonesia & 20.75 & 37.23 & 41.97 & 21.97 & 36.75 & 41.94 \\
\hline
\end{tabular}

Sumber : Data BPS (1990)

Dalam tabel 5 diperlihatkan bahwa disparitas pendapatan di pulau Jawa relatif lebih besar dibandingkan disparitas pendapatan di luar pulau Jawa. Sedangkan berdasarkan kriteria ketimpangan menurut 
persentase pendapat (World Bank) yang diterima oleh ketiga kelompok kelas pendapatan, yaitu $40 \%$ terendah, $40 \%$ sedang dan $20 \%$ tertinggi, maka Indonesia termasuk kategori normal. Ditunjukkan dalam tabel 6 (Indonesia) bahwa 40\% pendapat terendah menerima $20,75 \%$ dari total pendapatan, berarti lebih tinggi dari kriteria minimal $17 \%$ untuk kategori ketimpangan rendah yang ditetapkan oleh World Bank.

Dampak yang ditunjukkan dari ketimpangan antara kelompok masyarakat (spasial/daerah) yang disebabkan tidak hanya disparitas pendapatan, tetapi juga faktor nonekonomi (fasilitas, kesehatan, pendidikan dll) adalah tingkat kesenjangan sosial yang muncul ditengahtengah masyarakat itu sendiri hal ini memang terjadi, baik diakui maupun tidak.

Pengalaman kita mencatat (selama orde baru) setelah demonstrasi-demontrasi 'anti-China' dan antikorupsi' yang berakhir dengan peristiwa-peristiwa kerùsuhan 'anti-China' (Malari-1974, November 1980, Mei 1998), yang pada hakekatnya merupakan bukti bahwa kemakmuran (pertumbuhan) yang meningkat amat cepat, biasanya dibarengi dengan meningkatnya kesenjangan ekonomi dan sosial yang berarti pula terjadi peningkatan ketidakadilan sosial (Mubyarto, 1997).

\section{PENUTUP}

Periode perkembangan (reformasi) kita sekarang ini merupakan momentum tepat untuk menyadarkan bahwa kunci ketahanan nasional kita sebenarnya tidak semata-semata terletak di tangan 'para kongklomerat' yang sejauh ini selalu dianggap sebagai simbol usaha-usaha yang 'efisien' dan 'profesional', yang merupakan andalan kita dalam era persaingan global yang semakin ketat. Ketahanan ekonomi nasional sebenarnya sangat berkaitan dengan ke-handalan perekonomian rakyat- di mana di saat mandeg-nya ekonomi di saat sulit justru konsep ini yang menjadi alternatif solusi yang sebenarnya patut menjadi sokoguru perekonomian nasional. Namun bukan berarti pengembangan ekonomi rakyat dengan cara memberdayakan merupakan kebijakan karikatif yang dikhawatirkan hanya akan menghambat upaya peningkatan efisiensi ekonomi nasional, tetapi diyakini justru 
akan mendukung upaya-upaya ke arah itu (Mubyarto, 1997). Semua itu tidak lain Growth equity.

Visi kita dalam menghadapi era global harus benar-benar bertumpu pada kekuatan ekonomi rakyat. Namun demikian tidaklah berarti kita harus menghilangkan kekuatan konglomerat (yang harus hilang adalah sifat kongklomerasinya) sama sekali. Kedua kekuatan nasional ini (ekonomi rakyat plus kongklomerat masing-masing punya porsi yang sudah diatur dalam disiplin ketetapan) tidak berjalan sendiri-sendiri, tetapi harus lebur dalam sebuah kekuatan yang tangguh, handal dan mandiri. Upaya ini diharapkan untuk menutup kemungkinan pecahnya kesenjangan sosial dengan keresahan-keresahan sosial.

Hal yang senada juga diungkapkan oleh Sondakh (1994), yaitu perlunya para konglomerat melibatkan kelompok masyarakat pedesaan sebagai bagian integral dari proyek investasi mereka, supaya terjadi penciutan kesenjangan terutama sebagai dampak negatif dari intervensi pasar terhadap perekonomian desa; dampak ungkapan Amin Rais (1998) bahwa solusi pembangunan ekonomi masa mendatang yang paling tepat adalah memberdayakan pengusaha kecil tanpa memangkas yang sudah besar. Konsep ini diadopsi dari Presiden Mandela, yaitu tetap membiarkan pelaku pasar besar namun disertai beberapa regulasi baru yang lebih transparan dan terkendali (Bisnis Indonesia, 29/10/98).

Dengan demikian ada harapan terwujudnya perekonomian yang berjalan seimbang yaitu tidak dijalankan oleh satu kelompok tertentu, dan wujudnya pertumbuhan ekonomi yang diiringi pemerataan.

\section{DAFTAR PUSTAKA}

Dumairy, 1997. Perekonomian Indonesia. Jakarta: Penerbit Erlangga.

Mubyarto, 1997. Ekonomi Pancasila. Yogyakarta: Penerbit Aditya Media. 
Purnomo, D., 1998. Menyimak Sejarah Perekonomian Indonesia. Makalah diskusi, FE-UMS.

Sondakh, Lucky W, 1994. Pembangunan Daerah Dan Perekonomian Rakyat, Beberapa Ketimpangan Antar Kelompok Masyarakat, Prisma, Agustus 1994.

Suseno Hadi, 1990. Indikator Ekonomi, Jakarta: Penerbitan Kanisius.

Tambunan, Tulus, 1996. Perekonomian Indonesia. Jakarta: Penerbit Ghalia Indonesia.

Todaro, Michael, 1998 ed.6. Economic Development in the Third World. London: Longman, Inc. 